\title{
DSGOST regulates resistance via activation of autophagy in gastric cancer
}

\author{
Tae Woo Kim', Seon Young Lee', Mia Kim², Chunhoo Cheon' Bo-Hyoung Jang ${ }^{1}$ \\ Yong Cheol Shin ${ }^{1}$ and Seong-Gyu Ko ${ }^{1}$
}

\begin{abstract}
Danggui-Sayuk-Ga-Osuyu-Saenggang-Tang (DSGOST in Korean, Danggui-Sini-Jia-Wuzhuyu-Shengian-Tang in Chinese, and Tokishigyakukagoshuyushokyoto (TJ-38) in Japanese), a well-known traditional Korean/Chinese/Japanese medicine, has long been used to treat vascular diseases such as Raynaud's phenomenon (RP). However, anticancer effect of DSGOST remains elusive. In this study, we checked if DSGOST has an anticancer effect against gastric cancer cells, and investigated the mechanisms underlying DSGOST resistance. Moreover, DSGOST regulates chemoresistance in cisplatin-treated gastric cancer cells. Interestingly, DSGOST treatment induced the accumulation of GFP-LC3 puncta and increased the level of autophagy markers, such as LC3-II, ATG5, and Beclin-1, indicating activated autophagy. Furthermore, DSGOST could activate epithelial-to-mesenchymal transition (EMT) and exosomes via induction of autophagy. DSGOST in combination with TGF $\beta$ also induced autophagy and EMT. However, autophagy inhibition induces DSGOST-mediated cell death in gastric cancer cells. In addition, autophagy inhibition blocks the activation of DSGOST-mediated EMT markers including N-cadherin, Snail, Slug, vimentin, $\beta$-catenin, p-Smad2, and p-Smad3. Taken together, these findings indicated that prosurvival autophagy was one of the mechanisms involved in the resistance of gastric cancer to DSGOST. Targeting the inhibition of autophagy could be an effective therapeutic approach to overcome resistance to DSGOST in gastric cancer.
\end{abstract}

\section{Introduction}

Herbal medicines have long been used in East-Asian countries, including Korea, China, and Japan as alternative therapies for symptomatic relief from various disease ${ }^{1,2}$. Danggui-Sayuk-Ga-Osuyu-Saenggang-tang (DSGOST) is a traditional Korean herbal medicine that has been handed down to us from ancient Korean history, and is similar to the traditional Chinese herbal medicine Danggui-Sini-JiaWuzhuyu-Shengjian-Tang and the traditional Japanese herbal medicine Tokishigyakukagoshuyushokyoto (TJ$38)^{3-5}$. DSGOST is used in the therapy of patients having Raynaud's phenomenon (RP) who suffer from cold in the extremities $^{6}$. RP is episodic ischemia that occurs in

Correspondence:

S-G. Ko (epiko@khu.ac.kr)

${ }^{1}$ Department of Preventive Medicine, College of Korean Medicine, Kyung Hee University, Seoul, Korea

${ }^{2}$ Department of Cardiovascular and Neurologic Disease (Stroke center), College of Korean Medicine, Kyung Hee University, Seoul, Korea

Edited by B Zhivotovsky. response to cold environment exposure, and patients with $\mathrm{RP}$ suffer cold hypersensitivity on hands and feet ${ }^{7}$. In the hands of patients with RP, localized cooling increases the adrenergic neurotransmitter mechanism ${ }^{8}$. In patients with $\mathrm{RP}$, nervous system initiates exaggerated vasoconstriction in response to cooling 9 . The vasodilatory and anticoagulant ingredients of TJ-38 markedly relieved peripheral coldness $^{10,11}$. In addition, cold-induced vasoconstriction occurs due to the activation and translocation of adrenoceptor alpha 2C (ADRA2C), and cold condition induces Rho kinase activation ${ }^{12}$. In our previous study, we suggested that DSGOST blocks cold-induced Rho A activation and the endothelin-1 pathway in vascular smooth muscle and endothelial cells ${ }^{13}$.

$\mathrm{RP}$ is a known adverse effect of cancer chemotherapy ${ }^{14}$. it could be caused by various anticancer drugs, including cisplatin, vinblastine, and bleomycin ${ }^{15,16}$. A recent report indicates that DSGOST blocks tumor growth by suppressing angiogenesis in pancreatic cancer, and this report

\section{(c) The Author(s) 2018}

(c) (i) Open Access This article is licensed under a Creative Commons Attribution 4.0 International License, which permits use, sharing, adaptation, distribution and reproduction cc) in any medium or format, as long as you give appropriate credit to the original author(s) and the source, provide a link to the Creative Commons license, and indicate if changes were made. The images or other third party material in this article are included in the article's Creative Commons license, unless indicated otherwise in a credit line to the material. If material is not included in the article's Creative Commons license and your intended use is not permitted by statutory regulation or exceeds the permitted use, you will need to obtain permission directly from the copyright holder. To view a copy of this license, visit http://creativecommons.org/licenses/by/4.0/. 
A

DSGOST

DDMSO $\quad \square 100 \mu \mathrm{g} / \mathrm{ml} \quad \square 300 \mu \mathrm{gg} / \mathrm{ml} \quad \mathbf{\square} 500 \mu \mathrm{g} / \mathrm{ml}$

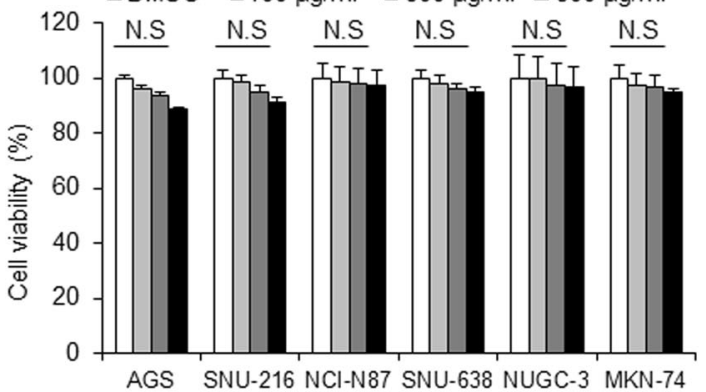

B

TJ-38
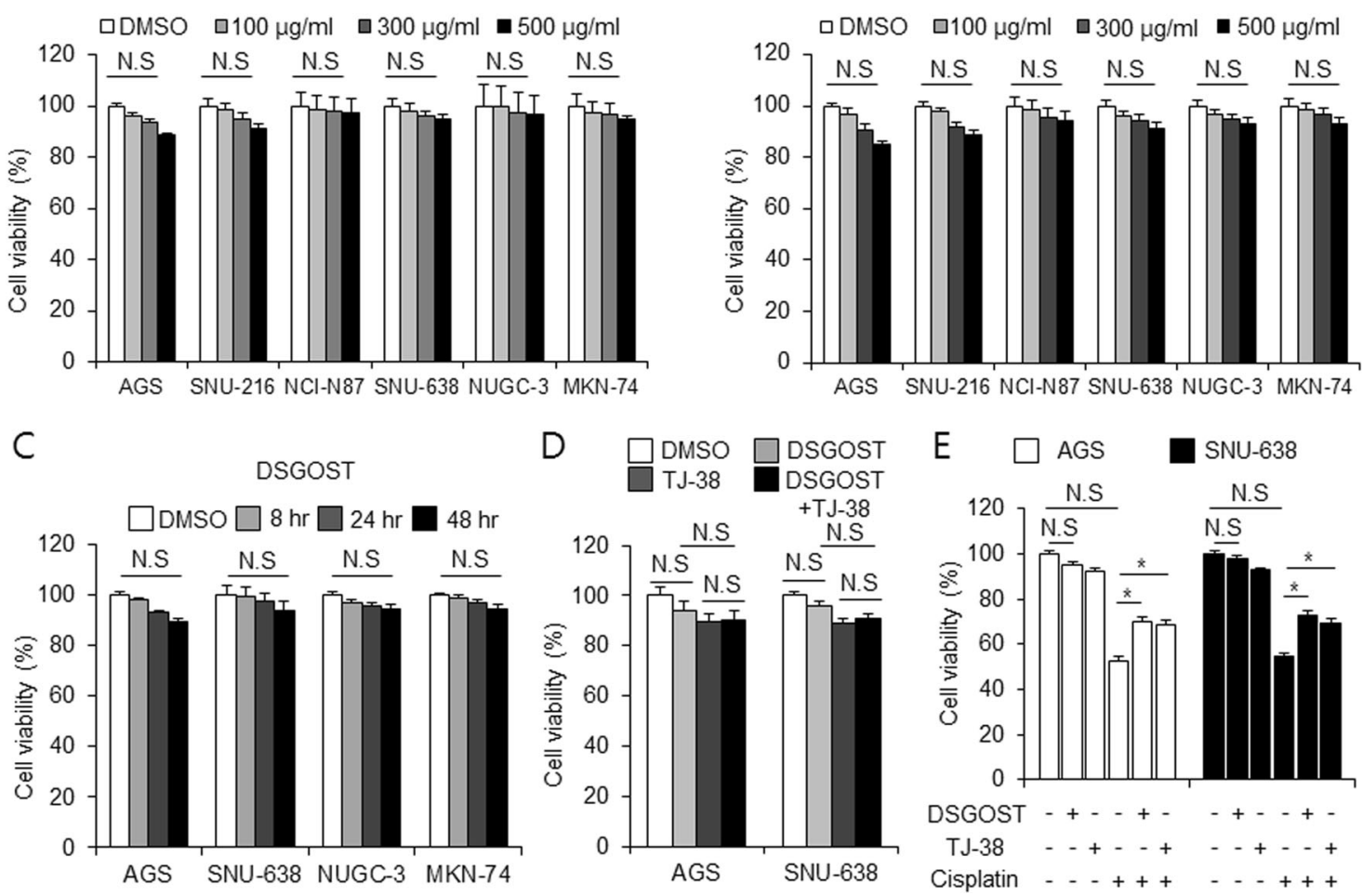

Fig. 1 Effect of DSGOST, TJ-38, and cisplatin in gastric cancer. a, b Cell viability of DSGOST and TJ-38 in gastric cancer cells measured using WST1 on 96-well plates, and DSGOST and TJ-38 were treated in a dose-dependent manner (100, 300, and $500 \mathrm{\mu g} / \mathrm{mL} ; 24 \mathrm{~h}$ ). c Cell viability of DSGOST in gastric cancer cells measured using WST-1 on 96-well plates, and DSGOST was treated in a time-dependent manner $(500 \mu \mathrm{gg} / \mathrm{mL} ; 8,24$, and $48 \mathrm{~h}) \mathbf{d}$

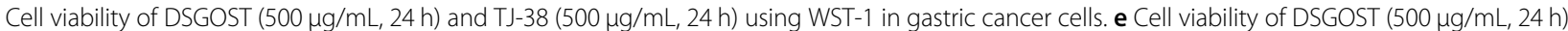
or TJ-38 $(500 \mu \mathrm{g} / \mathrm{mL}, 24 \mathrm{~h})$ in combination with cisplatin $(5 \mu \mathrm{M}, 24 \mathrm{~h})$ measured in gastric cancer cells using WST-1. Cell viability of DMSO-treated control cells was set at $100 \% ;{ }^{*} p<0.05$

also suggests that DSGOST has potential use in effectively reducing the tumor volume during cancer therapy ${ }^{17}$. DSGOST ingredients suggest a possibility for its use in anticancer therapy against many cancer types ${ }^{18-25}$. Various components of DSGOST have been studied for their anticancer effects, including cell death, apoptosis, and antiproliferation, and from the results, DSGOST shows a potential for use in cancer therapy.

Autophagy is a self-degradation process that occurs during starvation and growth deprivation and under stress conditions ${ }^{26}$. Autophagy has a dual role in promoting cell death and survival in cancer ${ }^{27,28}$. Some reports suggest that autophagy regulates chemoresistance in various cancer types ${ }^{29,30}$. Cisplatin and 5-fluorouracil (5-FU) induce cell death in various cancer cells; however, chemoresistant cancer cell lines promote a cell survival mechanism via activation of autophagy, and autophagy inhibition changes to therapeutic effect from chemoresistant to chemosensitive ${ }^{31}$. In addition, cisplatinmediated chemoresistance induced a pro-survival process via the activation of autophagy in nasopharyngeal carcinoma and displayed epithelial-mesenchymal transition (EMT) including the upregulation of vimentin ${ }^{32}$. Chemoresistance through autophagy activation acquires EMT phenotype, and crosstalk between EMT and autophagy suggests a new direction for chemotherapeutic strategy $^{33}$.

Therefore, we identified the dual effect of DSGOST and cisplatin for anticancer therapy in gastric cancer and studied the mechanisms underlying the resistance of gastric cancer to DSGOST. We also suggested that DSGOST-mediated gastric cancer cells acquire chemoresistance via autophagy induction and undergo EMT but autophagy inhibition causes DSGOST-induced cell death in gastric cancer.

\section{Results}

DSGOST regulates resistance in gastric cancer

To check the effect of DSGOST on various gastric cancer cells, we performed cell viability assay. DSGOST did not inhibit the cell viability of these cells in a dosedependent manner $(100,300$, and $500 \mu \mathrm{g} / \mathrm{mL}, 24 \mathrm{~h}$ ) 
(Fig. 1a). To investigate the effect of TJ-38, cell viability assay was performed in a dose-dependent manner (100, 300 , and $500 \mu \mathrm{g} / \mathrm{mL}, 24 \mathrm{~h}$ ) (Fig. 1b). TJ-38 did not affect cell viability of gastric cancer cells. We checked the effect of DSGOST in a time-dependent manner $(0,8,24,48 \mathrm{~h})$ on gastric cancer cell lines, and identified no effect on cell viability (Fig. 1c). Furthermore, treatment with DSGOST $(500 \mu \mathrm{g} / \mathrm{mL}, 24 \mathrm{~h})$ plus TJ-38 $(500 \mu \mathrm{g} / \mathrm{mL}, 24 \mathrm{~h})$ did not affect cell viability in gastric cancer cells (Fig. 1d). Next, we examined the effect of DSGOST $(500 \mu \mathrm{g} / \mathrm{mL}, 24 \mathrm{~h})$ or TJ-38 $(500 \mu \mathrm{g} / \mathrm{mL}, 24 \mathrm{~h})$ in combination with cisplatin (5 $\mu \mathrm{M}, 24 \mathrm{~h}$ ) (Fig. 1e). The combination of cisplatin with DSGOST or TJ-38 recovered cell viability of gastric cancer cells to a greater extent than cisplatin alone did. These findings suggest that DSGOST and TJ-38 induce chemoresistance in cisplatin-treated gastric cancer cells.

\section{DSGOST induces autophagy in gastric cancer}

Increasing reports suggest that autophagy plays an important role for resistance in cancer ${ }^{34}$. LC3-I is converted to LC3-II via lipidation during autophagy ${ }^{35}$. p62 binds directly to LC3 and is a useful marker of the induction of autophagy ${ }^{36}$. To identify the signaling pathway by which autophagy is activated following DSGOST treatment, we examined the expression levels of p62 and LC3 conversion in a dose-dependent manner (Fig. 2a). DSGOST treatment increased the expression of LC3-II and decreased that of p62. To identify whether autophagy plays a role in DSGOST resistance in a time-dependent manner, we performed the western blot assay to detect the expression of autophagy markers (Fig. 2b). We monitored the accumulation of LC3B, Beclin-1, and ATG5 and the downregulation of p62 levels in gastric cancer cells. Furthermore, AGS and SNU-638 cells were transfected with GFP-LC3 plasmid and then treated with DSGOST (Fig. 2c). The presence of GFP-LC3 puncta was used as an indicator of autophagosome formation. GFP-LC3 puncta was approximately sixfold higher in DSGOST-treated AGS and SNU-638 cells than in DMSO-treated gastric cancer cells. To study whether DSGOST and TJ-38 induce autophagy, western blot assay was performed. Consequently, DSGOST and TJ38 induce autophagy activation by the accumulation of LC3B and ATG5 and the degradation of p62 in AGS and SNU-638 cells (Fig. 2d). To check whether DSGOST or TJ-38 in combination with cisplatin regulates autophagy, we checked the expression of autophagy markers using western blot assay (Fig. 2e). DSGOST and TJ-38 cause chemoresistance by inducing the accumulation of LC3B and ATG5 and degradation of p62, whereas cisplatin induces cell death by activating autophagy. Moreover, unlike cisplatin alone, the combination of cisplatin with DSGOST or TJ38 induces chemoresistance by activating autophagy. Taken together, our findings suggest that DSGOST or TJ-
38 in combination with cisplatin regulates chemoresistance via the activation of autophagy in gastric cancer.

\section{DSGOST regulates autophagy flux}

To further investigate the role of autophagy during DSGOST treatment, autophagy inhibitors, including 3methyaldenine (3-MA) and chloroquine (CQ), were examined to arrest autophagy at early and late stages. We performed the WST-1 assay to determine whether 3-MA or CQ affected the DSGOST-induced cell viability in gastric cancer cells. The presence of the autophagy inhibitors did not affect cell viability in AGS and SNU-638 cells, whereas the treatment with 3-MA or CQ significantly decreased DSGOST-induced cell viability (Fig. 3a). To identify whether the induction of LC3B and ATG5 correlated with increased autophagic flux during DSGOST treatment, AGS and SNU-638 cells were treated with DSGOST in the presence or absence of 3-MA and $\mathrm{CQ}$ and western blot assay was performed. 3-MA reduced the activation of LC3B and ATG5 in DSGOST-mediated AGS and SNU-638 cells, whereas the treatment with CQ further increased the induction of LC3-II (Fig. 3b). CQ inhibits autophagy activation by blocking autophagolysosome formation ${ }^{37}$. This finding suggests that autophagy inhibition plays an important role in DSGOST-induced chemotherapy. To further confirm DSGOST-induced autophagy, AGS and SNU-638 cells were treated with DSGOST after transfection with LC3B- and ATG5specific siRNA (Fig. 3c, d). The knockdown of LC3B and ATG5 significantly decreased cell viability and inhibited DSGOST-induced autophagy. This evidence suggests that autophagy inhibition could suppress DSGOST-caused autophagy activation.

\section{DSGOST induces cell death via autophagy inhibition}

To examine whether DSGOST induces cell death via autophagy inhibition, AGS and SNU-638 cells were transfected by LC3B and ATG5 siRNA. DSGOST-treated LDH release was significantly enhanced in DSGOSTtreated LC3B and ATG5 siRNA transfected cells, whereas no increase was observed in control cells (Fig. 4a, b). We investigated whether autophagy inhibition affects the expression of pro-apoptotic factors using western blot assays. As expected, compared with DSGOST treatment in control cells, DSGOST treatment in LC3B or ATG5 knockdown cells resulted in a significant increase of cleaved caspase- 3 and -9 expression and PARP cleavage (Fig. 4a, b). Taken together, these results suggest that autophagy inhibition mediates DSGOST-induced cell death in gastric cancer.

\section{DSGOST leads to dissociation of Beclin-1-Bcl2 complex}

The interaction between Beclin-1 and Bcl-2 reportedly alters autophagy function of Beclin- ${ }^{38}$. To confirm 
A

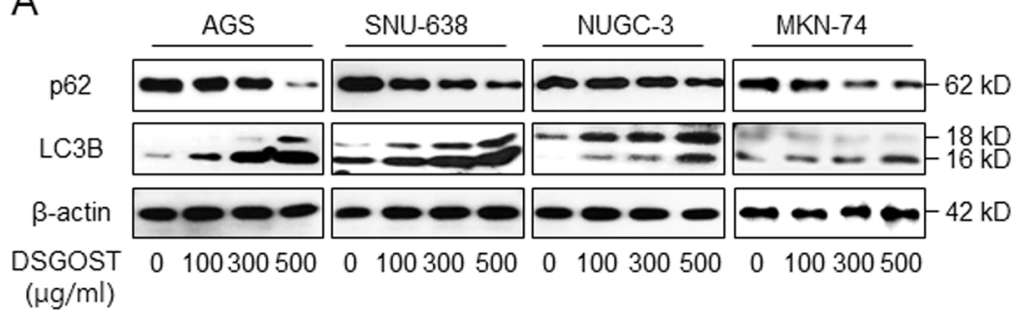

B

$B$

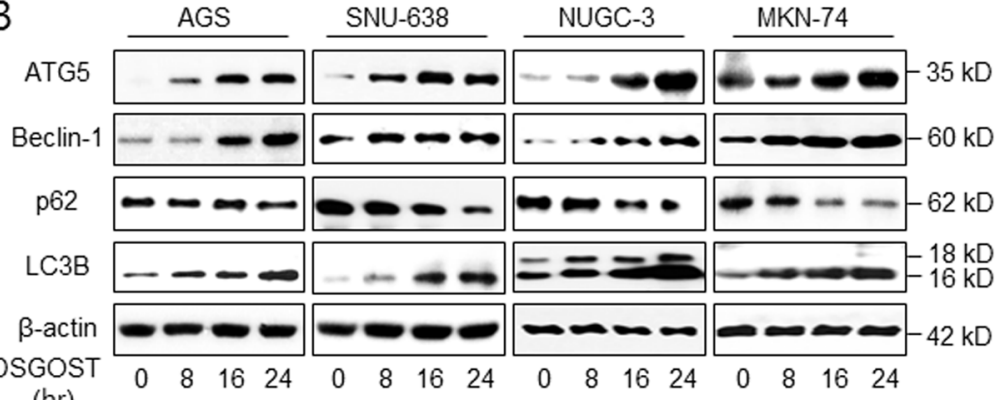

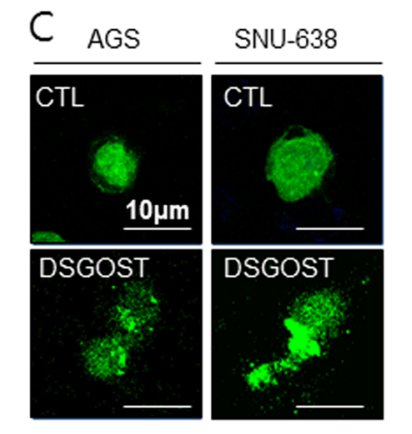

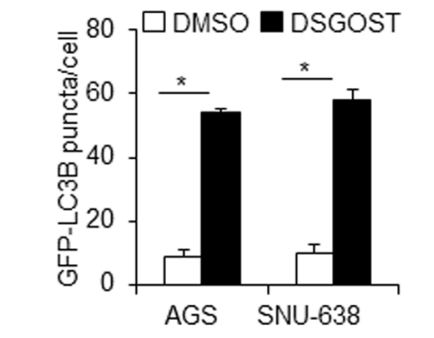
(hr)

D

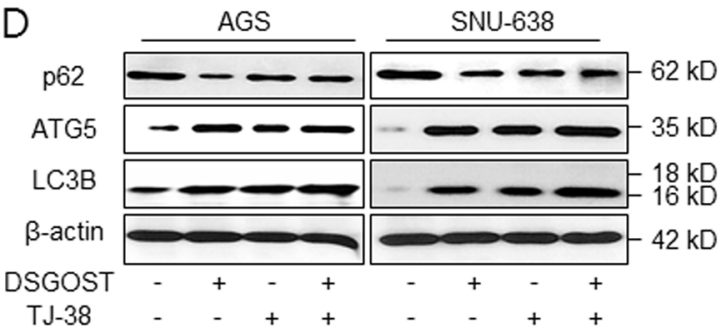

E p62

ATG5

LC3B

$\beta$-actin

DSGOST

TJ-38

Cisplatin

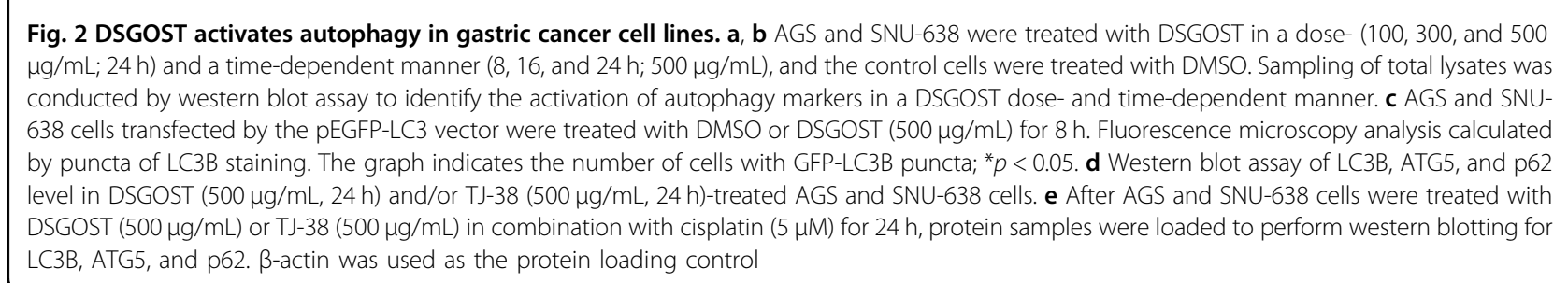

whether DSGOST can interfere with the interaction between Beclin-1 and Bcl-2, we examined the coimmunoprecipitation of Beclin-1 and Bcl-2 in DSGOSTmediated gastric cancer cells (Fig. 5a). First, Bcl-2 and Beclin-1 antibodies were immunoprecipitated in DSGOST-treated gastric cancer cells. In control cells, an interaction between $\mathrm{Bcl}-2$ and Beclin-1 was detected in the immunoprecipitated fractions by co-immunoprecipitation, indicating an interaction between $\mathrm{Bcl}-2$ and Beclin-1. However, DSGOST treatment in these cells induced a time-dependent disruption of this complex.

\section{DSGOST induces resistance via activation of the AMPKa/ ULK1 pathway}

A previous study identified that AMP-activated protein kinase $\alpha(\mathrm{AMPK} \alpha)$ activates autophagy by activating serine/threonine kinases 1 (ULK1) and inhibiting the mammalian target of rapamycin (mTOR)/ribosomal protein S6 kinase p70S6K (p70S6K) signaling ${ }^{39}$. Therefore, using western blotting, we investigated whether the AMPK $\alpha / \mathrm{ULK} 1$ and mTOR/p70S6K pathways were involved in DSGOST-induced autophagy in gastric cancer cells. DSGOST reduced in the phosphorylation levels of mTOR in a time-dependent manner, whereas total mTOR levels were not affected by DSGOST treatment (Fig. 5b). In addition, DSGOST induced a reduction in p70S6K phosphorylation, indicating its potent inhibitory effect by DSGOST on mTOR/p70S6K signaling (Fig. 5b). AMPK, by interacting with ULK1, is involved in the initiation of autophagosome formation ${ }^{40}$. We explored the activation of AMPK $\alpha$ and ULK1 in DSGOST-mediated gastric cancer cells. AMPK $\alpha$ and ULK1 could be activated by 

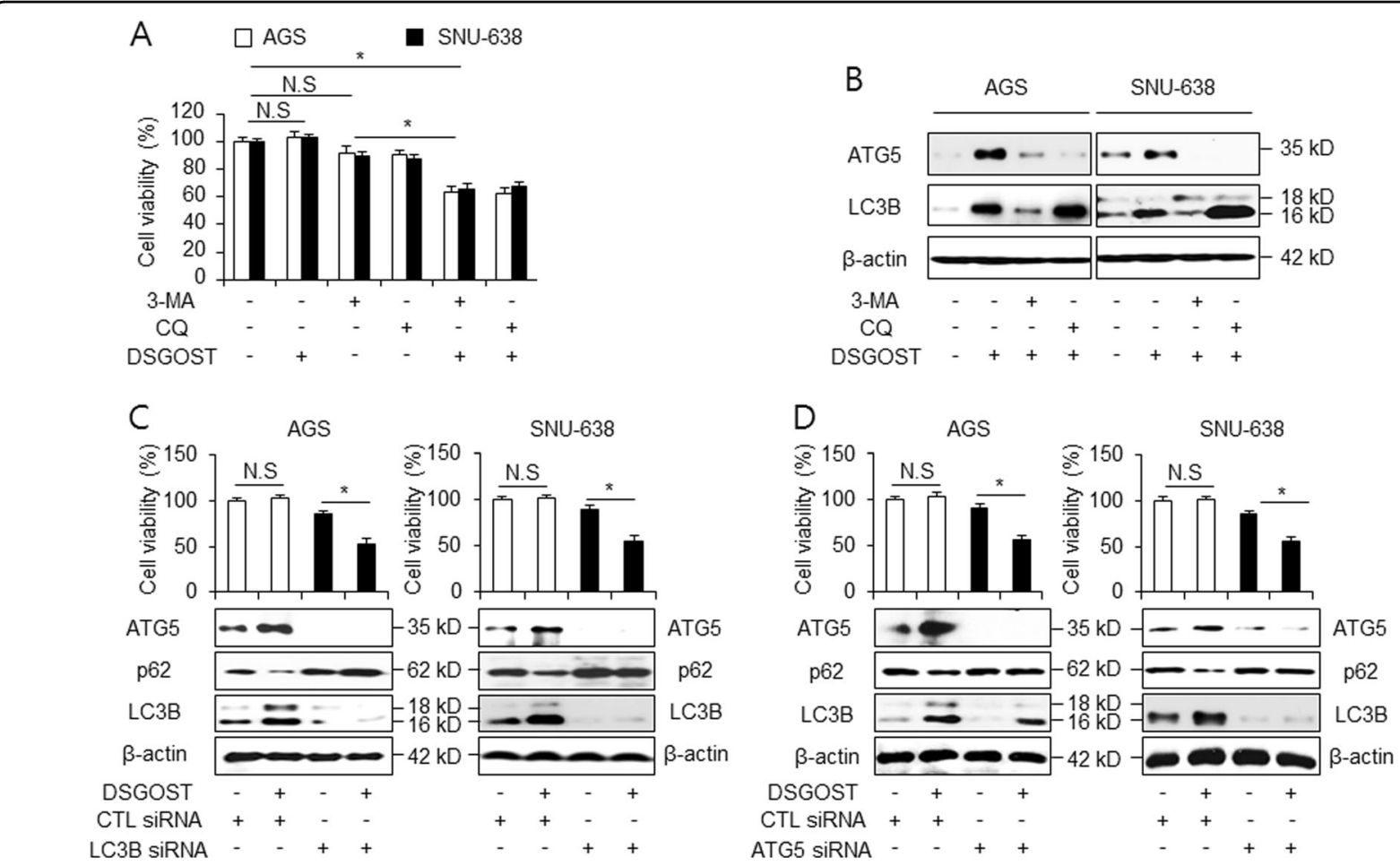

Fig. 3 Autophagy inhibition regulates DSGOST-induced autophagic flux. a AGS and SNU-638 cells were treated with DSGOST (500 $\mu \mathrm{g} / \mathrm{mL}, 24 \mathrm{~h}$ ) in the absence or presence of the autophagy inhibitors 3-methylamine (3-MA, $5 \mathrm{mM})$ and chloroquine $(\mathrm{CQ}, 10 \mu \mathrm{M})$ for $24 \mathrm{~h}$. Cell viability was performed and analyzed by WST-1 assay; ${ }^{*} p<0.05$. b After AGS and SNU-638 cells were treated with DSGOST ( $\left.500 \mu \mathrm{gg} / \mathrm{mL}, 24 \mathrm{~h}\right)$ with or without 3-MA $(5 \mathrm{mM})$ and $\mathrm{CQ}(10 \mu \mathrm{M})$ for $24 \mathrm{~h}, \mathrm{LC} 3 \mathrm{~B}$ and ATG5 levels were examined using western blotting. $\mathbf{c}$ After transfection with control or LC3B siRNA in the presence and absence of DSGOST $(500 \mu \mathrm{g} / \mathrm{mL}, 24 \mathrm{~h})$, expression levels of LC3B, p62, and ATG5 were performed by western blot assay in AGS and SNU-638 cells. d AGS and SNU-638 cells were treated with DSGOST $(500 \mu \mathrm{g} / \mathrm{mL}, 24 \mathrm{~h})$ in the presence or absence of ATG5 siRNA
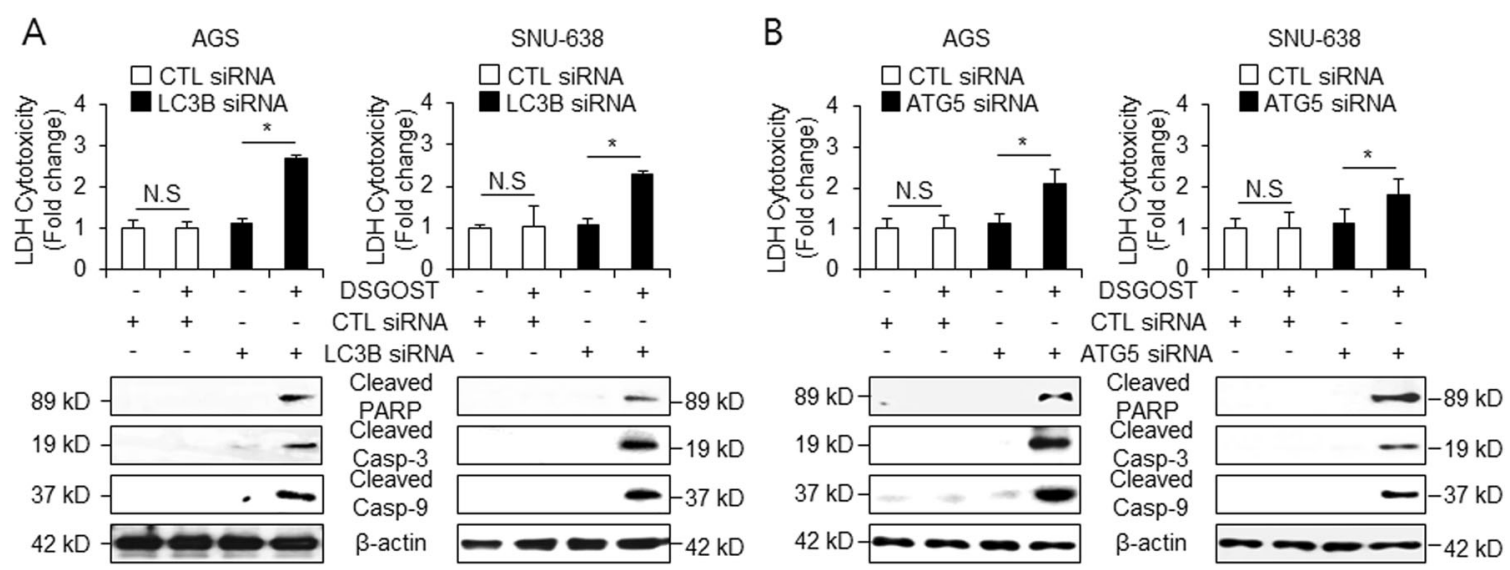

Fig. 4 Autophagy inhibition enhances DSGOST-induced cell death. $\mathbf{a}$, b After transfection by LC3B or ATG5 siRNA in AGS and SNU-638 cells, cell cytotoxicity was investigated with/without DSGOST (500 $\mu \mathrm{g} / \mathrm{mL}, 24 \mathrm{~h}$ ) using LDH assay, and cleaved caspase-3, caspase-9, and PARP were used to identify apoptosis by DSGOST in the presence or absence of LC3B or ATG5 siRNA using western blotting. $\beta$-actin was used as the protein loading control

DSGOST in a time-dependent manner in AGS and SNU638 cells (Fig. 5b). As autophagy promotes cell survival, our study investigated whether the inhibition of AMPK augmented DSGOST cytotoxicity. As expected, Compound $\mathrm{C}$, a well-known inhibitor of AMPK, mediated DSGOST-induced cell death, which was indicated by a 


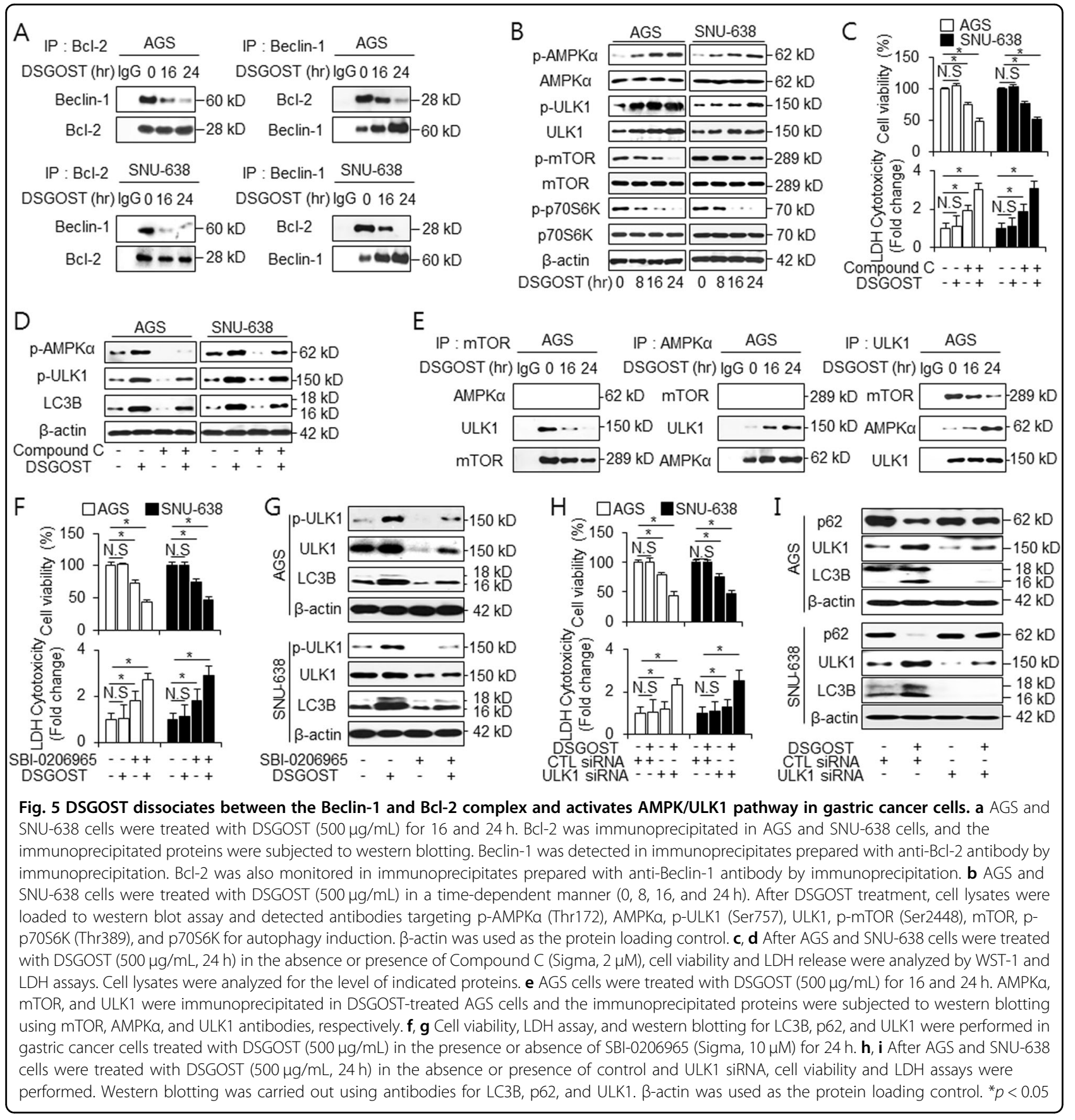

decrease in cell viability and an increase in LDH release in the DSGOST + Compound C group compared with the other groups (Fig. 5c). The inhibition of AMPK $\alpha$ resulted in lower expression levels of p-AMPK $\alpha$, p-ULK1, and LC3-II in the DSGOST + Compound C group than in the DSGOST group, indicating that AMPK $\alpha$ inhibition interrupted DSGOST-mediated autophagy (Fig. 5d).

To further determine how DSGOST regulates autophagy signaling, AGS cells were exposed to DSGOST in a time-dependent manner, and the immunoprecipitated fractions were isolated using antibodies, such as mTOR, AMPK $\alpha$, and ULK1 (Fig. 5e). In this study, mTOR did not interact with AMPK $\alpha$ in DSGOST-mediated AGS cells. However, an interaction between mTOR and ULK1 was observed in immunoprecipitated fractions and DSGOST caused a time-dependent disruption of this interaction (Fig. 5e). AMPK $\alpha$ did not interact with ULK1 in DMSOtreated AGS cells. Interestingly, DSGOST induced a timedependent interaction of AMPK $\alpha$ and ULK1 (Fig. 5e). Our finding was identified by immunoprecipitation using 


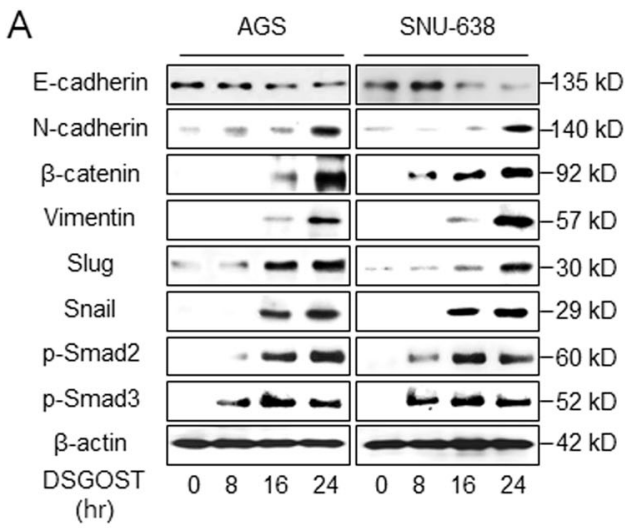

B

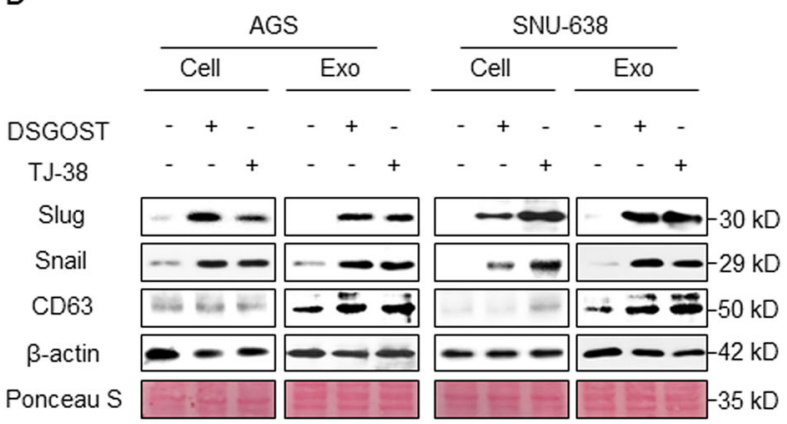

C

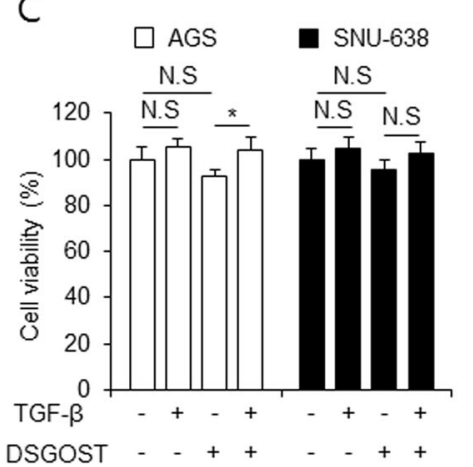

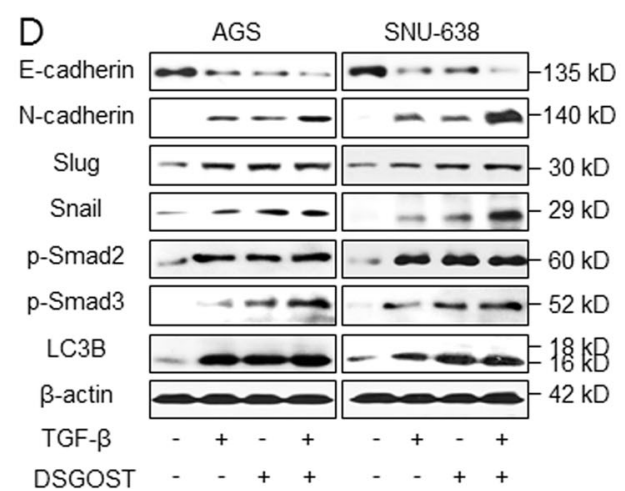

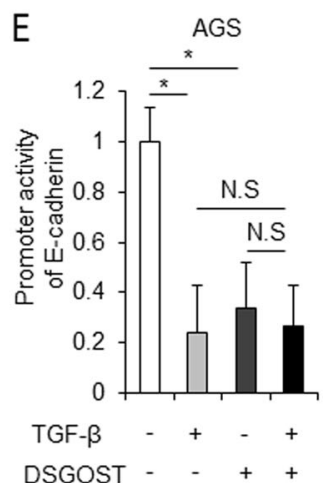

Fig. 6 DSGOST induces EMT in gastric cancer. a AGS and SNU-638 cells were treated with DSGOST (500 $\mu \mathrm{g} / \mathrm{mL}$ ) in a time-dependent manner (0, 8 , 16, and $24 \mathrm{~h}$ ). After DSGOST treatment, extracted total proteins were subjected to western blotting using antibodies for EMT markers, such as Ecadherin, N-cadherin, $\beta$-catenin, vimentin, Slug, Snail, and Smad signaling, including p-Smad2 and p-Smad3. b AGS and SNU-638 cells were treated with DSGOST or TJ-38 and exosomes were collected from cell supernatants. Exosomes and cell lysates were quantified by Ponceau $S$ staining. Exosomes were also examined by western blotting using the exosome marker CD63 and EMT markers, such as Snail and Slug. c, d Cell viability and western blotting analysis of EMT markers and Smad signaling in AGS and SNU-638 cells after TGF- $\beta 1$ (5 ng/mL, 24 h) and DSGOST (500 $\mu \mathrm{g} / \mathrm{mL}, 24 \mathrm{~h}$ ) treatment; ${ }^{*} p<0.05$. e AGS cells were transfected with a reporter luciferase vector containing an E-cadherin promoter $(-368 \sim+51)$, and were treated with TGF- $\beta 1(5 \mathrm{ng} / \mathrm{mL}, 24 \mathrm{~h})$ or/and DSGOST $(500 \mu \mathrm{g} / \mathrm{mL}, 24 \mathrm{~h})$. The luciferase activity was normalized to the activity of Renilla luciferase; * $p<0.05$

ULK1 antibody. Taken together, mTOR and ULK1 were found to interact during DMSO treatment, but DSGOST caused the dissociation of mTOR and ULK1 and induced the interaction of AMPK $\alpha$ and ULK1 (Fig. 5e). These findings suggest that the activation of the AMPK $\alpha /$ ULK1 pathway is an important event in DSGOST-induced prosurvival autophagy.

Next, we treated with either the presence or the absence of SBI-0206965, which is a small molecule inhibitor for ULK1 in DSGOST-treated gastric cancer cells. Consistently, our results showed that DSGOST + SBI0206965 treatment induced a reduction of cell viability and an increase of LDH release compared with DSGOST treatment (Fig. 5f). The pharmacological inhibition of ULK1 resulted in lower expression levels of p-ULK1 and LC3-II in the DSGOST + SBI-0206965 group compared with the DSGOST group, indicating that the inhibition of ULK1 interrupted DSGOST-mediated autophagy (Fig. 5g). To gain more insight into the role of ULK1 in regulating DSGOST-induced autophagy, AGS and SNU-
638 cells were transfected with ULK1 siRNA. The knockdown of ULK1 induced a decrease of cell viability and an increase of LDH release in DSGOST-treated gastric cancer cells (Fig. 5h). Furthermore, the ULK1 knockdown cells decreased LC3B level and slightly reduced p62 level in DSGOST-treated gastric cancer cells compared with the control cells (Fig. 5i). These findings indicated that ULK1 inhibition could effectively overcompensate for DSGOST resistance and enhance the sensitivity of gastric cancer cells to DSGOST-mediated cell death.

\section{DSGOST induces autophagy and EMT in gastric cancer}

Increasing evidences suggest that increasing EMT in cancer plays a powerful role in enabling malignancy features $^{41}$. Furthermore, protective autophagy regulates chemoresistance and EMT via TGF- $\beta /$ Smad signaling ${ }^{42}$. To determine whether DSGOST promotes EMT in gastric cancer cells, the exposure of these cells to DSGOST was studied in a time-dependent manner, and EMT 

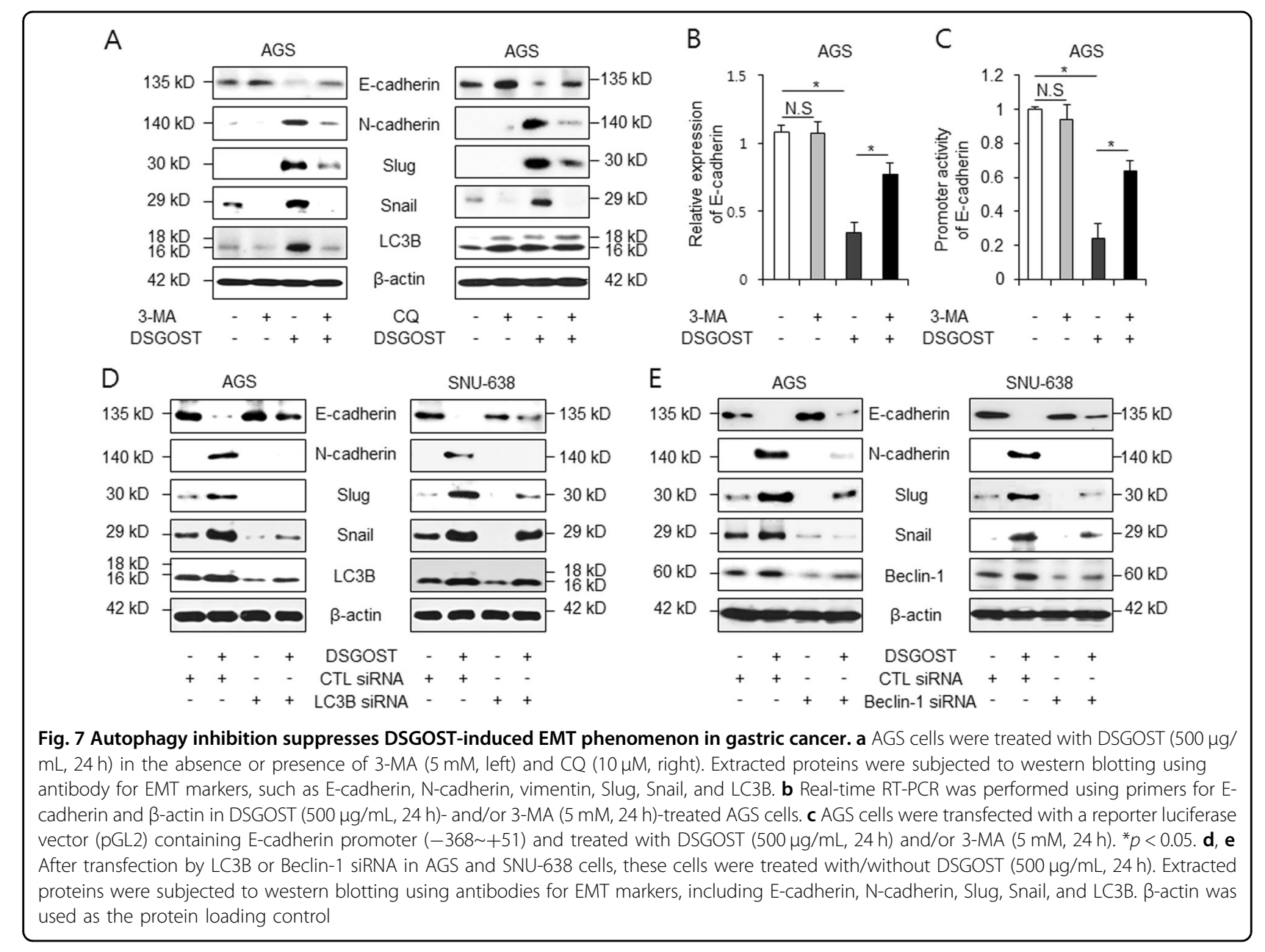

markers, such as E-cadherin, N-cadherin, $\beta$-catenin, vimentin, Slug, Snail, p-Smad2, and p-Smad3, were examined. We observed that E-cadherin decreased in DSGOST-treated gastric cancer cells, whereas all other accumulated in DSGOST-treated cells (Fig. 6a). These data indicate that DSGOST-induced autophagy triggers EMT in gastric cancer cells. A recent report suggested that cancer-derived exosomes are an important mediator of autophagy and EMT signaling ${ }^{43}$. Robust evidence also indicates that autophagy plays a key role in chemoresistance, exosome release, and EMT in tumor cells ${ }^{44}$. Western blotting revealed that exosomes purified from DSGOST or TJ-38-treated gastric cancer cells were highly positive for the exosome markers, such as CD63 (Fig. 6b). Our results suggest that DSGOST- or TJ-38-treated cell lysates and exosomes induce the upregulation of Slug and Snail (Fig. 6b). Therefore, these findings suggest that DSGOST or TJ-38-induced autophagy regulates EMT signaling via exosome release.

TGF $\beta$ is the core EMT transcription factor and autophagy promotes TGF $\beta$-induced $\mathrm{EMT}^{45}$. We investigated whether DSGOST regulates EMT in TGF $\beta$-treated gastric cancer cells. Similar to DMSO-treated cells, cell viability of DSGOST-mediated gastric cancer cells was not affected by TGF $\beta$ treatment (Fig. 6c). To explore whether DSGOST in combination with TGF $\beta$ induces autophagy and EMT in gastric cancer cells, we examined LC3B and EMT markers. Western blot results demonstrated a significant decrease of E-cadherin and an increase of LC3B, $\mathrm{N}$-cadherin, Slug, Snail, p-Smad2, and p-Smad3 in DSGOST and TGF $\beta$-treated AGS and SNU-638 cells (Fig. 6d). We constructed a luciferase reporter driven by the E-cadherin promoter. Luciferase assay analyzed the activity of the E-cadherin promoter in TGF $\beta$ and DSGOST-treated AGS cells. These cells showed significantly decreased activity of this promoter, indicating EMT activation (Fig. 6e). These findings suggest that DSGOST promotes autophagy and EMT in TGF $\beta$-treated gastric cancer cells.

\section{Autophagy inhibition blocks DSGOST-caused EMT}

To characterize the relationship between DSGOSTinduced autophagy and EMT, DSGOST was treated with 3-MA or CQ in AGS cells. As a result, the expression of 
LC3B, N-cadherin, Slug, and Snail was dramatically decreased compared with the expression observed with the treatment with DSGOST alone (Fig. 7a). Transcriptional regulation of E-cadherin regulates EMT, and Snail is a repressor of E-cadherin in tumor cells ${ }^{46,47}$. To elucidate the effect of autophagy on the EMT process, realtime RT-PCR was performed. We identified that Ecadherin expression was not changed by 3-MA in AGS cells (Fig. 7b). However, E-cadherin expression had higher mRNA levels in DSGOST plus 3-MA-treated AGS cells than in DSGOST-treated cells. To confirm the role of Ecadherin promoter activity in DSGOST plus 3-MAtreated AGS cells, we performed promoter luciferase reporter assays. We found that the E-cadherin promoter had a higher luciferase reporter activity in DSGOST plus 3-MA-treated AGS cells than in DSGOST-treated cells (Fig. 7c). To further clarify the association between autophagy and EMT, gastric cancer cells were transfected by LC3B and Beclin-1 siRNAs and treated with DSGOST. These experiments showed lower expression of LC3B, Beclin-1, N-cadherin, Slug, and Snail than control cells (Fig. 7d, e). Taken together, these findings suggest that autophagy inhibition regulates DSGOST-induced EMT signaling in gastric cancer.

\section{Discussion}

Currently, there is now emerging interest and scientific evidence in the use of DSGOST as an anticancer therapeutic. However, the mechanisms underlying chemoresistance, EMT, and exosome in DSGOST-induced autophagy remain poorly understood. In this study, we found that DSGOST regulates resistance via prosurvival autophagy in gastric cancer and induces the expression of EMT markers in exosomes and cell lysates. We identified that autophagy inhibition mediates DSGOST-induced cell death and suppresses EMT. Our study has showed that autophagy plays an important role in cell survival and death of DSGOST-treated gastric cancer cells.

Previous studies have reported on the use of DSGOST in the therapy of vascular disease, such as $R P^{4,48}$. $R P$ is caused by anticancer agents, such as bleomycin and cisplatin and anticancer therapy has several early or late side effects, including RP and hypersensitivity syndrome ${ }^{49,50}$. In cancer chemotherapy, it is of utmost importance to prevent the side effects of anticancer agents. Our robust evidence based on a clinical trial of DSGOST performed on Korean female patients provided evidence of its potential for use as a powerful drug for RP therapy ${ }^{51}$. We hypothesized that DSGOST would help resolve RP that may occur due to chemotherapy using anticancer drug such as cisplatin. Previous results identified that DSGOST inhibited VEGF-induced tumor angiogenesis in endothelial cells and suggested it as a noble strategy for some relief during cancer chemotherapy ${ }^{17}$. We found that
DSGOST and TJ-38-induced autophagy significantly reduced cisplatin-mediated cell death. Therefore, these findings suggest that a prosurvival autophagic response was associated with chemoresistance in DSGOST plus cisplatin-treated gastric cancer cells. The success of anticancer therapy is frequently limited by drug alone or multidrug resistance ${ }^{52}$. Increasing studies have shown that autophagy plays a powerful role in chemoresistance ${ }^{53}$. Some recent reports suggest that protective autophagy confers chemoresistance to anticancer drugs, including cisplatin, in gastric cancer ${ }^{54}$. In this study, DSGOST and TJ-38 induced autophagy by enhancing LC3-II and ATG5 and reducing p62 in gastric cancer cells, thus contributing to chemoresistance.

DSGOST dissociated the Beclin-1-Bcl-2 complex to initiate autophagy and activated AMPK/ULK1 signaling. When AGS cells were treated with DSGOST, AMPK interacted with ULK1 to regulate DSGOST-mediated autophagy and inhibited the mTOR/p70S6K pathway, which inactivates autophagy. Consistent with this finding, we found that AMPK activation after DSGOST treatment induces autophagy through ULK1 phosphorylation in gastric cancer cells. The inhibition of AMPK and ULK1 decreased DSGOST-induced autophagy in gastric cancer cells, thus leading to an increase in DSGOST-caused cell death. According to a recent report, protective autophagy was correlated with acquired drug resistance, and the inhibition of autophagy was suggested as a noble therapeutic strategy in cancer ${ }^{55}$. O'Donovan et al. also reported that 5-fluorouracil (5-FU) and cisplatin-resistant cell lines show a higher autophagy activation response than chemo-sensitive cell lines; further, autophagy inhibition has a chemotherapeutic effect in drug-resistant cancer cells ${ }^{31}$. Taken together, our data identified that DSGOST regulates resistance via autophagy induction in gastric cancer cells, whereas autophagy inhibition induces cell death in DSGOST-treated gastric cancer cells.

Starvation-mediated autophagy is critical for cellular invasion via EMT activation in hepatocellular carcinoma cells, and TGF $\beta 1$ stimulates EMT and autophagy via the activation of Smad signaling in cancer cells ${ }^{56}$. Protective autophagy promotes EMT process, and EMT also promotes drug resistance ${ }^{57}$. Our findings indicate that DSGOST treatment regulates EMT by reducing Ecadherin and increasing of mesenchymal markers including $\mathrm{N}$-cadherin and vimentin in gastric cancer cells. In addition, EMT regulators, such as Snail and Slug, were upregulated in lysates and exosomes derived from DSGOST-treated gastric cancer cells, and TGF $\beta 1$ plus DSGOST treatment induced EMT signaling via phosphorylation of Smad2 and Smad3. We suggest that the DSGOST-induced EMT activation may contribute to resistance via autophagy activation. The inhibition of DSGOST-mediated autophagy blocked the acquisition of 
the EMT phenotype and induced DSGOST-stimulated cell death. These findings suggest that autophagy inhibition is a potential therapeutic strategy in DSGOSTtreated gastric cancer.

Exosomes are small membrane vesicles derived from the endosomal system and also contribute to EMT in cancer $^{58}$. A recent report indicates that cells may communicate with neighbors via exosome secretion, and this has recently gained attention for understanding chemoresistance mechanisms ${ }^{59}$. A recent study reported that exosomes derived from docetaxel-resistant breast cancer cells reduced the antiproliferative effects ${ }^{60}$. Autophagy is a part of the endolysosomal membrane system and is linked to exosome production ${ }^{61}$. Furthermore, when exosomes derived from gefitinib-induced PC9 cells were exposed to cisplatin-treated cells, gefitinib-treated exosomes significantly decreased the antitumor effects of cisplatin by activating autophagy ${ }^{62}$. Exosomes derived from DSGOST or TJ-38-treated gastric cancer cells were highly positive for the exosomal marker protein CD63 and the upregulation of Slug and Snail was found within these exosomes. These results mean that DSGOST-induced autophagy regulates resistance via EMT process and exosome release.

To conclude, for the first time, we demonstrated that DSGOST in combination with cisplatin suggests a new therapeutic strategy for anticancer therapy and may inhibit the chemotherapy adverse effects of RP. Furthermore, our findings propose new insights into the molecular mechanisms underlying DSGOST-induced resistance via autophagy activation in gastric cancer cells.

\section{Materials and methods DSGOST extraction}

DSGOST was extracted as previously described ${ }^{17}$. This herbal formula was originally designed for cancer therapy. The nine ingredients and their amounts (g) were prepared as follow: $1 \mathrm{~g}$ of Angelica gigas, $1 \mathrm{~g}$ of Cinnamomum cassia Blume, $1 \mathrm{~g}$ of Paeonia lactiflora Pallas, $1 \mathrm{~g}$ of Akebia root, $0.67 \mathrm{~g}$ of Asarum, $0.67 \mathrm{~g}$ of Glycyrrhiza uralensis Fischer, $1.67 \mathrm{~g}$ of Zizyphus jujuba var. inermis Rehder, $0.67 \mathrm{~g}$ of Evodia fruit, and $1.33 \mathrm{~g}$ of Zingiber officinale Rosc. The mixtures were obtained by Han-Poong Pharm Co. Ltd (Jeonjoo, Repubic of Korea). Herbal medicines were mixed together, soaked in water, and extracted by $100{ }^{\circ} \mathrm{C}$ treatment for $2 \mathrm{~h}$. The extract was then filtered, evaporated, and lyophilized to make DSGOST powder. This was stored at $-80^{\circ} \mathrm{C}$ until use.

\section{Cell culture}

The human gastric cancer cell lines (AGS, SNU-216, NCI-N87, SNU-638, SNU-668, and MKN-74) were purchased from the Korean Cell Line Bank (Cancer Research Center, Seoul National University, Seoul, Korea). Cells were cultured in RPMI1640 medium (Welgene) supplemented with $10 \%$ fetal bovine serum (JR Scientific) and $100 \mu \mathrm{g} / \mathrm{mL}$ antibiotics $(100 \mathrm{U} / \mathrm{mL}$ penicillin and $100 \mu \mathrm{g} /$ $\mathrm{mL}$ streptomycin, Welgene) in a $5 \% \mathrm{CO}_{2}$ humidified incubator at $37^{\circ} \mathrm{C}$.

\section{Cell viability assay}

Cell viability was determined by the WST-1 assay. It was performed according to the manufacturer's instructions (Roche). Cells were seeded to each well of a 96-well plate $\left(1 \times 10^{4}\right.$ cells/well $)$ and incubated for $24 \mathrm{~h}\left(5 \% \mathrm{CO}_{2}\right.$ humidified incubator at $\left.37^{\circ} \mathrm{C}\right)$. On day 1 after cell seeding, cells were treated with various doses $(100,300$, and 500 $\mu \mathrm{g} / \mathrm{mL})$ of DSGOST and for various times $(4,16$, and 24 h). The autophagy inhibitors 3-MA (5 mM, Sigma) and CQ $(20 \mu \mathrm{M}$, Sigma) were added to the RPMI1640 medium for $24 \mathrm{~h}$. Gastric cancer cells were treated with TJ-38 (Tsumura \& Co., Japan) in a dose-dependent manner $(100,300$, and $500 \mu \mathrm{g} / \mathrm{mL})$. These cells was treated with cisplatin (5 $\mu$ M, Sigma), SBI-0206965 (5 $\mu$ M, Sigma), and TGF- $\beta 1$ ( $5 \mathrm{ng} / \mathrm{mL}$, R\&D Systems). Then, $10 \mu \mathrm{L}$ of WST-1 reagent was added in a 96-well plate, and the conversion of the WST-1 reagent into chromogenic formazan was evaluated with a spectrophotometer (Molecular devices, USA) after $1 \mathrm{~h}$.

\section{LDH assay}

AGS and SNU-638 cells $\left(1 \times 10^{4}\right.$ cells/well $)$ were seeded into a 96-well plate with growth medium. To determine the LDH (Thermo Scientific Pierce) activity in supernatants, $100 \mu \mathrm{L}$ of the reaction mixture was added, and incubation for $30 \mathrm{~min}$ was performed in a dark room. The LDH activity measured the absorbance of the samples at 490 or $492 \mathrm{~nm}$ using ELISA reader.

\section{Transfection}

AGS and SNU-638 cells $\left(2 \times 10^{5}\right.$ cells/well $)$ in a six-well plate were transfected with these double-stranded siRNAs (30 nmol/mL), including LC3B (Sigma), ULK1, Beclin-1, and ATG5 (Santacruz) for $24 \mathrm{~h}$ by the Lipofectamine 2000 reagent (Invitrogen) method according to the manufacturer's protocol and recovered in RPMI1640 medium (Welgene) containing 10\% fetal bovine serum (JR Scientific) and $100 \mu \mathrm{g} / \mathrm{mL}$ antibiotics $(100 \mathrm{U} / \mathrm{mL}$ penicillin and $100 \mu \mathrm{g} / \mathrm{mL}$ streptomyhcin, Welgene) for $24 \mathrm{~h}$. After recovery, viable cells were calculated by WST-1.

\section{Isolation of total RNA and protein}

Total RNA from gastric cancer cells $\left(2 \times 10^{6}\right.$ cells/well $)$ in $100 \mathrm{~mm}$ cell culture dish was prepared using Trizol reagent according to the manufacturer's protocols (Invitrogen). Protein sampling was collected in RIPA buffer (Biosesang) containing a protease inhibitor cocktail (Sigma) on ice for $30 \mathrm{~min}$ and were passed through an 18- 
gauge needle, and spin down. The supernatant was analyzed for protein content using the BCA method (Thermo Scientific).

\section{Real-time PCR and western analysis}

The E-cadherin expression level was measured by realtime PCR using cDNA synthesized from $5 \mu \mathrm{g}$ of total RNA and a reverse transcription kit (Promega). Reactions were performed in triplicate for each sample using an $A B I$ Power SYBR green PCR Master Mix (Applied Biosystems) with E-cadherin-specific primers (5'-GAACGCATTGCCACATACAC-3' (sense) and 5'-GAATTCGGGCTTG TTGTCAT-3' (antisense)) on a Roche LightCycler 96 (Roche). RNA quantify was normalized to $\beta$-actin primers (5'-AAGGCCAAC CGCGAGAAGAT-3' (sense) and 5'TGATGACCTGGCCGTCAGG-3' (antisense)), and gene expression was quantified according to the $2^{-\Delta \mathrm{Ct}}$ method. To conduct the western blot assay, gastric cancer cells were solubilized in radioimmunoprecipitation assay (RIPA) lysis buffer (50 mM/L Tris- $\mathrm{HCl}$ (pH 7.4), $150 \mathrm{mM} /$ $\mathrm{L} \mathrm{NaCl}, 1 \% \mathrm{NP} 40,0.25 \%$ sodium deoxycholate, $1 \mathrm{mM} / \mathrm{L}$ phenylmethylsulfonylfluoride, $1 \mathrm{mM} / \mathrm{L}$ sodium orthovanadate, $1 \times$ sigma protease inhibitor cocktail) and protein was measured using a standard bicinchoninic acid assay. Equal amounts of protein $(20 \mu \mathrm{g})$ were size-fractionated by $8 \sim 15 \%$ SDS-PAGE and then transferred onto an NC membrane (Millipore Corporation). Membranes were blocked by incubation for $30 \mathrm{~min}$ with $5 \%$ skim milk/PBS$\mathrm{T}$, and incubated overnight at $4{ }^{\circ} \mathrm{C}$ with primary antibodies diluted in $1 \times$ PBST buffer. The following primary antibodies were used: $\beta$-actin, Bcl-2, Beclin-1, ULK1, and Atg5 (Santa Cruz, 1:1000); LC3B and p62 (Sigma, 1:1000); CD63 (Abcam, 1:1000); cleaved caspase-3, caspase-9, -PARP, p62, AMPKa, p-AMPKa (Thr172), mTOR, pmTOR (Ser2448), p70S6K, p-p70S6K (Thr389), p-ULK1 (Ser757), E-cadherin, $\mathrm{N}$-cadherin, $\beta$-catenin, vimentin, $\mathrm{p}$ Smad2, p-Smad3, Slug, and Snail (Cell Signaling, 1:1000). The membranes were washed three times with PBST buffer. The secondary antibody was diluted in PBST or TBST buffer and was added for $40 \mathrm{~min}$ at room temperature. The following secondary antibodies were used: anti-rabbit IgG HRP-linked antibody and anti-mouse IgG HRP-linked antibody (KPL, 1:6000). The membranes were washed six times with PBST buffer for $1 \mathrm{~h}$. The blots were visualized by Western Chemiluminescent HRP Substrate (Millipore).

\section{Quantification of pEGFP-LC3 puncta}

AGS and SNU-638 cells $\left(2 \times 10^{5}\right.$ cells/well $)$ in a six-well plate were transfected with pEGFP-LC3 using Lipofectamine 2000 (Invitrogen), and then treated with $500 \mu \mathrm{g} / \mathrm{mL}$ DSGOST for $8 \mathrm{~h}$. A pEGFP-LC3B-positive punctate pattern was observed by confocal microscopy. Confocal microscopy was conducted using a ZEISS LSM5 PASCAL confocal microscope with 405- and 488-nm excitation lasers.

\section{Luciferase reporter assay}

To evaluate the E-cadherin promoter activity, AGS cells $\left(2 \times 10^{5}\right.$ cell/well $)$ were seeded in a six-well plate and transfected with $2.5 \mu \mathrm{g}$ of pGL2 luciferase vector (Promega) and reporter luciferase vector containing an Ecadherin promoter $(-368 \sim+51)$ after $24 \mathrm{~h}$ using Lipofectamine 2000 agent (Invitrogen). Luciferase activity was measured $36 \mathrm{~h}$ after transfection in three independent cultures using a dual-luciferase reporter assay kit (Promega) on Molecular Devices Filter Max F3 (Molecular Devices). The luciferase activity was normalized to activity of the Renilla luciferase.

\section{Immunoprecipitation (IP)}

We extracted cell lysates from AGS and SNU-638 cells $\left(2 \times 10^{6} /\right.$ well $)$ on a $100 \mathrm{~mm}$ cell culture plate in a buffer containing $50 \mathrm{mM}$ Tris- $\mathrm{HCl}, \mathrm{pH} 7.5,250 \mathrm{mM} \mathrm{NaCl}, 5$ $\mathrm{mM}$ EDTA, $0.5 \%(\mathrm{v} / \mathrm{v}) \mathrm{NP}-40$ and a protease inhibitor cocktail (Sigma). We incubated anti-Bcl-2 (Santa Cruz), anti-Beclin-1 (Santa Cruz), mTOR (Santa Cruz), AMPK (Cell Signaling), and ULK1 (Cell Signaling) with lysate at $4{ }^{\circ} \mathrm{C}$ for $16 \mathrm{~h}$. We used the protein A/G PLUS agarose (Santa Cruz) to pull down immunocomplexes. We washed precipitates three times with a solution containing $50 \mathrm{mM}$ Tris- $\mathrm{HCl}, \mathrm{pH} 7.5,250 \mathrm{mM} \mathrm{NaCl}, 5 \mathrm{mM}$ EDTA, and $0.5 \%(\mathrm{v} / \mathrm{v}) \mathrm{NP}-40$.

\section{Exosome isolation}

Exosomes were obtained from the supernatant of untreated and DSGOST $(0,300$, and $500 \mu \mathrm{g} / \mathrm{mL})$-treated AGS and SNU-638 cells according to the manufacturer's protocols (Total Exosome Isolation Reagent (from cell culture media), Thermo Fisher Scientific). Protein concentration was measured using the BCA method (Thermo Scientific). Samples with equal protein loading $(15 \mu \mathrm{g})$ were also quantified by Ponceau S staining and were subjected to western blot assay. Positive exosomes were detected by the exosome marker, CD63 (Abcam).

\section{Statistical analysis}

All results were confirmed in at least three independent experiments; Student's $t$ tests were used for comparisons of means of quantitative data between groups and $p<0.05$ was considered statistically significant.

\section{Acknowledgements}

This work was supported by a grant from the Korean Medicine R\&D project of the Ministry of Health and Welfare (HI11C2110 and HI12C1889).

\footnotetext{
Author details

${ }^{1}$ Department of Preventive Medicine, College of Korean Medicine, Kyung Hee University, Seoul, Korea. ${ }^{2}$ Department of Cardiovascular and Neurologic
} 
Disease (Stroke center), College of Korean Medicine, Kyung Hee University, Seoul, Korea

\section{Authors' contributions}

T.W.K., S.Y.L., and C.C. conducted the experiments and analyzed the data. T.W.K. M.K., B.-H.J., Y.C.S., and S.-G.K. designed the project and revised and drafted the manuscript. All authors read and approved the final manuscript.

\section{Conflict of interest}

The authors declare that they have no conflict of interest.

\section{Publisher's note}

Springer Nature remains neutral with regard to jurisdictional claims in published maps and institutional affiliations.

Received: 12 December 2017 Revised: 20 April 2018 Accepted: 23 April 2018

Published online: 29 May 2018

\section{References}

1. Chang, Y. S., Seo, E. K., Gyllenhaal, C. \& Block, K. Panax ginseng: a role in cancer therapy? Integr. Cancer Ther. 2, 13-33 (2003).

2. Hu, Y. et al. Chinese herbal medicine-derived compounds for cancer therapy: a focus on hepatocellular carcinoma. J. Ethnopharmacol. 149, 601-612 (2013)

3. Lee, Y. H. et al. Literature review on Danggwisayeokgaohsuyusaenggang-tang. Korean J. Orient. Physiol. Pathol. 28, 1-8 (2014).

4. Nishida, S. et al. Effects of a traditional herbal medicine on peripheral blood flow in women experiencing peripheral coldness: a randomized controlled trial. BMC Complement Altern. Med. 15, 105 (2015).

5. Kimura, Y., Tanaka, A. \& Sato, H. Efficacy of Kampo formula Tokishigyakukagoshuyushokyoto for cold syndrome evaluated with a novel clinical method using a patient-based questionnaire database. Kamp-. Med. 63, 299-304 (2012).

6. Kanal, S., Okano, H. \& Abe, H. Efficacy of toki-shigyakuka-gosyuyu-syukyo-to (danggui-sini-jia-wuzhuyu-shengjiang-tang) on peripheral circulation in autonomic disorders. Am. J. Chin. Med. 25, 69-78 (1997).

7. Bowling, J. C. \& Dowd, P. M. Ratnaud's disease. Lancet 361, 2078-2080 (2003).

8. Gryn, Garfield, John, Ludbrook \& Alan, Wilson Cold hypersensitivity in Raynaud's phenomenon. Circulation 44, 254-264 (1971).

9. Fardoun, M. M., Nassif, J., Issa, K., Baydoun, E. \& Eid, A. H. Raynaud's Phenomenon: a brief review of the underlying mechanisms. Front Pharmacol. 7 , 438 (2016).

10. Shoji, N., Umeyama, A., Takemoto, T., Kajiwara, A. \& Ohizumi, Y. Isolation of evodamine, a powerful cardiotonic principle, from Evodia rutaecarpa Bentham (Rutaceae). J. Pharm. Sci. 75, 612-613 (1986).

11. Yakubo, S. et al. The effectiveness of the kampo preparation Toki-shigyaku-kagoshuyu-to for treatment of sensation of cold due to spinal cord infarction. Int. Med. J. 20, 216-217 (2013)

12. Bailey, S. R., Eid, A. H., Mitra, S., Flavahan, S. \& Flavahan, N. A. Rho kinase mediates cold-induced construction of cutaneous arteries: role of alpha2Cadrenoceptor translocation. Circ. Res. 94, 1367-1374 (2004).

13. Cho, S. G. et al. Herbal prescription, DSGOST, prevents cold-induced Rho A activation and endothelin-1 production in Endothelial cells. Evid. Based Complement. Altern. Med. 2014, 549307 (2014).

14. Khouri, C. et al. Drug-induced Raynaud's phenomenon: beyond $\beta$ adrenoceptor blockers. Br. J. Clin. Pharmacol. 82, 6-16 (2016).

15. Hansen, S. W., Olsen, N., Rossing, N. \& Rorth, M. Vascular toxicity and the mechanism underlying Raynaud's phenomenon in patients treated with cisplatin, vinblastine and bleomycin. Ann. Oncol. 1, 289-292 (1990).

16. Hansen, S. W. \& Olsen, N. Raynaud's phenomenon in patients treated with cisplatin, vinblastine, and bleomycin for germ cell cancer: measurement of vasoconstrictor response to cold. J. Clin. Oncol. 7, 940-942 (1989).

17. Choi, H. S. et al. DSGOST inhibits tumor growth by blocking VEGFNEGFR2activated angiogenesis. Oncotarget 7, 21775-21785 (2016).

18. Kim, W. J., Lee, S. J., Choi, Y. D. \& Moon, S. K. Decursin inhibits growth of human bladder and colon cancer cells via apoptosis, G1-phase cell cycle arrest and extracellular signal-regulated kinase activation. Int. J. Mol. Med. 25, 635-641 (2010).

19. Choi, H. S. et al. Decursin in Angelica gigas Nakai (AGN) enhances Doxorubicin chemosensitivity in NCl/ADR-RES ovarian cancer cells via inhibition of Pglycoprotein expression. Phytother. Res. 30, 2020-2026 (2016).

20. Lin, C. Y. et al. Cinnamomum cassia extracts reverses TGF- $\beta 1$-induced epithelial -messenchymal transition in human lung adenocarcinoma cells and suppresses tumor growth in vivo. Environ. Toxicol. 32, 1878-1887 (2017).

21. Wu, C. et al. Cinnamaldehyde induces apoptosis and reverse epitherialmessenchymal transition through inhibition of Wnt/ $\beta$-catenin pathway in non-small cell lung cancer. Int. J. Biochem. Cell Biol. 84, 58-74 (2017).

22. Lee, S. M. et al. Paeoniae Radix, a Chinese herbal extract, inhibit hepetoma cells growth by inducing apoptosis in a p53 independent pathway. Life Sci. 71 2267-2277 (2002).

23. Xu, M. Y., Lee, D. H., Joo, E. J., Son, K. H. \& Kim, Y. S. Akebia saponin PA induces autophagic and apoptotic cell death in AGS human gastric cancer cells. Food Chem. Toxicol. 59, 703-708 (2013).

24. Li, T. Y. \& Chiang, B. H. 6-shogaol induces autophagic cell death then triggered apoptosis in colorectal adenocarcinoma HT-29 cells. Biomed. Pharmacother. 93, 208-217 (2017)

25. Ebrahimi, S., Mollaei, H. \& Hoshyar, R. Ziziphus Jujube: a review study of its anticancer effects in various tumor models invitro and invivo. Cell. Mol. Biol. (Noisy-Le.-Grand.). 63, 122-127 (2017).

26. He, C. \& Klionsky, D. J. Regulation mechanisms and signaling pathways of autophagy. Annu. Rev. Genet. 43, 67-93 (2009).

27. Alva, A. S., Gultekin, S. H. \& Baehrecke, E. H. Autophagy in human tumors: cell survival or death? Cell Death Differ. 11, 1046-1048 (2004).

28. Shintani, T. \& Klionsky, D. J. Autophagy is health and disease: a double-edged sword. Science 306, 990-995 (2004).

29. Wu, T. et al. Autophagy facilitates lung adenocarcinoma resistance to cisplatin treatment by activation of AMPK/mTOR signaling pathway. Drug Des. Dev. Ther. 9, 6421-6431 (2015).

30. Belounis, A. et al. Autophagy is associated with chemoresistance in neuroblastoma. BMC Cancer 16, 891 (2016).

31. O'Donovan, T. R., O'Sullivan, G. C. \& McKenna, S. L. Induction of autophagy by drug-resistant esophageal cancer cells promotes their survival and recovery following treatment with chemotherapeutics. Autophagy 7, 509-524 (2011).

32. Su, Z. Autophagy inhibition impairs the epithelial-mesenchymal transition and enhances cisplatin sensitivity in nasopharyngeal carcinoma. Oncol. Lett. 13, 4147-4154 (2017).

33. Akalay, I. et al. EMT impairs breast carcinoma cell susceptibility to CTLmediated lysis through autophagy induction. Autophagy 9, 1104-1106 (2013).

34. Zheng, H. C. The molecular mechanisms of chemoresistance in cancers. Oncotarget 8, 59950-59964 (2017).

35. Ichimura, Y. et al. A ubiquitin-like system mediates protein lipidation. Nature 408, 488-492 (2000).

36. Komatsu, M. et al. Homeostatic levels of p62 control cytoplasmic inclusion body formation in autophagy-deficient mice. Cell 131, 1149-1163 (2007).

37. Tasdemir, E. et al. Methods for assessing autophagy and autophagic cell death. Methods Mol. Biol. 445, 29-76 (2008).

38. Pattingre, S. et al. BCl-2 antiapoptotic proteins inhibit beclin 1-dependent autophagy. Cell 122, 927-939 (2005).

39. Kim, J., Kundu, M., Viollet, B. \& Guan, K. L. AMPK and mTOR regulate autophagy through direct phosphorylation of Ulk1. Nat. Cell Biol. 13, 132-141 (2011).

40. Wong, P. M., Puente, C., Ganley, I. G. \& Jiang, K. The ULK1 complex: sensing nutrient signals for autophagy activation. Autophagy 9, 124-137 (2013).

41. Yang, J. et al. N1-guanyl-1,7-diaminoheptane sensitizes bladder cancer cells to doxorubicin by preventing epitherial-mesenchymal transition through inhibition of eukaryotic transition initiation factor 5A2 activation. Cancer Sci. 105, 219-227 (2014)

42. Zou, M. et al. AEG-1/MTDH-activated autophagy enhances human malignant glioma susceptibility to TGF- $\beta 1$-triggered epithelial-mesenchymal transition Oncotarget 7, 13122-13138 (2016).

43. Blacwell, R. H., Foreman, K. E., \& Gupta, G. N. The role of cancer-derived exosomes in tumorigenicity \& epithelial-to-mesenchymal transition. Cancers (Basel) 9, E105 (2017)

44. Mowers, E. E., Sharifi, M. N. \& Macleod, K. F. Autophagy in cancer metastasis. Oncogene 36, 1619-1630 (2017).

45. Li, J. et al. Autophagy promotes hepatocellular carcinoma cell invasion through activation of epithelial-mesenchymal transition. Carcinogenesis $\mathbf{3 4}$ 1343-1351 (2013). 
46. Peinado, H., Portillo, F. \& Cano, A. Transcriptional regulation of cadherins during development and carcinogenesis. Int. J. Dev. Biol. 48, 365-375 (2004).

47. Batlle, E. et al. The transcription factor snail is a repressor of E-cadherin gene expression in epithelial tumour cells. Nat. Cell Biol. 2, 84-89 (2000).

48. Chen, Q. Q., Han, X., Wang, W. M., Zhao, L. \& Chen, A. Danggui Sini Decoction ameliorates Myelo suppression in animal model by upregulating Thrombopoietin expression. Cell Biochem. Biophys. 71, 945-950 (2015).

49. Guillot, B., Bessis, D. \& Dereure, O. Mucocutaneous side effects of antineoplastic chemotherapy. Expert Opin. Drug Saf. 3, 579-587 (2004).

50. Atas, E., Korkmazer, N., Artik, H. A., Babacan, O. \& Kesik, V. Raynaud's phenomenon in a child with medulloblastoma as a late effect of chemotherapy. J. Cancer Res. Ther. 11, 666 (2015).

51. Ko, Y. et al. The efficacy and safety of Danggui-Sayuk-Ga-Osuyu-Saenggangtang on Korean patients with cold hypersensitivity in the hands: study protocol for a pilot, double-blind, randomized, placebo-controlled, parallel-group clinical trial. Trials 18, 268 (2017).

52. Zahreddine, H. \& Borden, K. L. Mechanisms and insights into drug resistance in cancer. Front. Pharmacol. 4, 28 (2013).

53. Dong, $X$. et al. Aquaporin 3 facilitates chemoresistance in gastric cancer cells to cisplatin via autophagy. Cell Death Discov. 2, 16087 (2016).

54. Dalby, K. N., Tekedereli, I., Lopez-Berestein, G. \& Ozpolat, B. Targeting the prodeath and prosurvival functions of autophagy as novel therapeutic strategies in cancer. Autophagy 6, 322-329 (2010).
55. Vucicevic, L. et al. Compound C induces protective autophagy in cancer cells through AMPK inhibition-independent blockade of Akt/mTOR pathway. Autophagy 7, 40-50 (2011).

56. Pang, $M$. et al. Autophagy links $\beta$-catenin and Smad signaling to promote epithelial-mesenchymal transition via upregulation of integrin linked kinase. Int. J. Biochem. Cell Biol. 76, 123-134 (2016).

57. Akalay, I. et al. Epithelial-to-mesenchymal transition and autophagy induction in breast carcinoma promote escape from T-cell-mediated lysis. Cancer Res. 73, 2418-2427 (2013).

58. Kahlert, C. \& Kalluri, R. Exosomes in tumor microenvironment influence cancer progression and metastasis. J. Mol. Med. (Berlin) 91, 431-437 (2013).

59. Azmi, A. S., Bao, B. \& Sarkar, F. H. Exosomes in cancer development, metastasis, and drug resistance: a comprehensive review. Cancer Metastas-. Rev. 32 , 623-642 (2013).

60. Chen, W. X. et al. Exosomes from docetaxel-resistant breast cancer cells alter chemosensitivity by delivering microRNAs. Tumour Biol. 35, 9649-9659 (2014).

61. Baixauli, F., Lopez-Otin, C. \& Mittelbrunn, M. Exosomes and autophagy: coordinated mechanisms for the maintenance of cellular fitness. Front. Immunol. $\mathbf{5}$ 403 (2014).

62. Li, X. Q. et al. Exosomes derived from gefitinib-treated EGFR-mutant lung cancer cells alter cisplatin sensitivity via up-regulating autophagy. Oncotarget 7, 24585-24595 (2016). 